\title{
Lignin in Woody Plants under Water Stress: A Review
}

\author{
Ubirajara Contro Malavasi ${ }^{1}$, Antony Swick Davis ${ }^{2}$, Marlene de Matos Malavasi ${ }^{1}$ \\ ${ }^{1}$ Centro de Ciências Agrárias, Universidade Estadual do Oeste do Paraná - UNIOESTE, Marechal Candido Rondon/PR, Brazil \\ ${ }^{2}$ Department of Forest, Rangeland, and Fire Sciences, University of Idaho, Moscow, United States of America
}

\begin{abstract}
Under tropical and sub-tropical conditions, perennial woody plants most often encounter drought stress due to erratic rainfall, which has become compounded as result of recent climatic changes. Control of the efficiency and safety of water transport from roots to shoots is fundamental for plant survival under water stressed conditions. Lignin plays an important role in the life of terrestrial plants. Depending upon the stress, lignin plays protective, sustaining and disruptive roles in addition to its involvement in plant growth, development and defense responses. This review aims to present and summarize reported evidence on the possible role of lignin of plant tissue (in special woody species) in response to water limiting condition which is expected to increase because of environment changes.
\end{abstract}

Keywords: tree survival, seedling production, tree hydraulics, wood anatomy.

\section{Lignina em Plantas Lenhosas sob Estresse Hídrico: Uma Revisão}

\section{RESUMO}

Sob condições tropicais e sub-tropicais, plantas lenhosas frequentemente deparam-se com condições de estresse hídrico devido à irregularidade das precipitações pluviométricas, agravada nos dias de hoje pelas mudanças climáticas. O controle da eficiência e segurança no transporte de água das raízes para tecidos aéreos é fundamental para a sobrevivência em condições estressantes. A lignina desempenha um papel importante na vida das plantas terrestres. Dependendo do estresse, a lignina desempenha função protetora, de sustentação, e disruptiva no crescimento, desenvolvimento e respostas de defesa das plantas terrestres. Esta revisão objetiva apresentar e resumir evidências relatadas sobre o possível papel da lignina no tecido vegetal (especialmente em espécies lenhosas) em resposta a condições limitantes de água aumentadas, resultantes de mudanças ambientais.

Palavras-chave: sobrevivência de árvores, produção de mudas, hidráulica de árvores, anatomia do lenho. 


\section{INTRODUCTION}

Damage to plants in response to abiotic and biotic stresses is a worldwide ecologic and economic concern. Recent and predicted climate changes exacerbate this concern (Lobell \& Gourdji, 2012). Environmental stresses not only have adverse effects on plant growth and productivity but also are expected to become more variable, severe, and widespread in decades to come. Prolonged and repeated severe environmental stresses affecting plant growth and development would bring down long-lasting effects in woody plants as a result of its long-term growth period. Plant tolerance to stress englobes a variation in the detail network and cascade of events or reactions leading to alleviation of potential stress-induced cellular injuries depending on the plant species that have evolved through environmental changes.

The development of lignin biosynthesis has been considered to be one key factor that allowed plants to flourish in terrestrial ecosystems. Therefore, to understand and improve water stress tolerance in plants by manipulating lignin in wood plant tissues becomes a necessity if tree survival and biomass production are to be increased and profitable in face of future climate changes. Plasticity in lignin biosynthesis may be an important feature in understanding future species distribution as impacted by changing water stress patterns.

\section{TERRESTRIAL PLANTS AND WATER STRESS}

Terrestrial plants are continuously exposed to changing environmental conditions that could potentially threaten survival. Water availability, which can be constrained by drought, salinity, or freezing is a major factor limiting plant growth and development in both agricultural and forestry settings. The effects of water limitation will likely worsen in the coming decades because of expected climate changes and the growing scarcity of fresh water available for irrigation caused by urbanization and the depletion of aquifers (Pennisi, 2008).

Access to water at the time of tissue development is a major environmental factor limiting plant productivity. The responses of plants to water stress and their relative importance for crop productivity vary with species, soil type, nutrients and climate. One-third of potential arable land suffers from inadequate water supply, and the productivity of the remainder is periodically reduced by drought (Arnell, 2004). In order to avoid limiting availability of water in the soil solution plants have evolved mechanisms to withstand water stress. Those mechanisms may include change in leaf anatomy and ultrastructure, reduction of leaf size, thickening of leaf cell wall, increase in number of large vessels, and reduction of stomata (Lisar et al., 2012).

Plants experience water stress either when the roots face water deficit or because of the high transpiration rate. Controlling the efficiency and safety of water transport from roots to shoots is fundamental for the survival of terrestrial plants under water stressed conditions. With changes predicted in seasonal drought patterns, especially under climate change, traditional/evolved mechanisms of drought tolerance or avoidance may no longer be uniquely able to guide plants to survival (De Micco \& Aronne, 2012).

Water stress resulting from the withholding of water not only changes the physical environment for plant growth but also its physiology. Widely different plant responses have been reported depending on how the water stress is imposed to plants. Short-versus rapid-term and long- versus gradual-term essays results in a variety of responses. Prolonged and repeated severe stresses affecting growth and development would bring down long-lasting effects in woody plants as a result of its long-term growth period (Osakabe et al., 2012).

Terrestrial plant species possess distinctive indicators of stress tolerance at whole plant, tissue or cellular levels (Munns, 2002). Most adult woody plants can withstand periods of soil water deficits. However, seedlings of those very same species often cannot because of shallow root systems relative to available soil water (Pinto et al., 2012).

\section{PLANT XYLEM ANATOMY}

Water is transported from the roots to the leaves through the xylem of woody plants under negative pressure (Tyree, 1997). When water levels decrease, soil water potentials drop, pressure gradient in the xylem increases, and vessels are more likely to cavitate and lose their hydraulic conductivity due to water stress. Uninterrupted transport of water through the xylem 
is essential for plant growth and survival because it replaces water lost by transpiration and allows stomata to remain open for photosynthesis (Ambrose et al., 2015).

Xylem cavitation can affect plant productivity and survival (McDowell et al., 2008; Brodribb \& Cochard, 2009) while xylem vulnerability to cavitation is correlated with drought tolerance (Maherali et al., 2004; Pockman \& Sperry, 2000; Tyree et al., 2003). However, lower vulnerability to cavitation is correlated with lower hydraulic conductivity (Cochard et al., 1992; Hacke et al., 2006).

The trade-off between safety and efficiency of plant water transport will depend on the pit area and the pit membrane structure. Inter-vessel pits, composed of small and thin porous membrane with overarching secondary cell walls are the main pathway for the water flow that prevent the passage of air bubbles from an embolized vessel to a conducting vessel (Jansen et al., 2009).

The extent in which wood plant species can conduct water and resist xylem cavitation in the stem is determined by vessel adaptation. Failure of the conductive tissue to resist high negative pressures can result in collapse of the conduit walls resulting in cavitation. Formation of gas bubbles, or embolism that cause blockage to the flow of water within conduits can result from cavitation. Embolism can be reversed (Shen et al., 2007) and may also play a developmental role in the formation of heartwood (Sperry et al., 1991).

Wide vessels have the advantage of a greater hydraulic efficiency (i.e., water transport capacity) because hydraulic efficiency of a xylem vessel increases with the fourth power of its diameter (Tyree \& Zimmermann, 2002).

Terrestrial plants may also be able to reduce the risk of conduits imploding in response to the tensile forces acting on the walls by reducing the lumen diameter relative to the wall thickness of vessels (Hacke et al., 2001) or fibers (Jacobsen et al., 2005). This decrease in lumen diameter could reduce wood porosity. As a result, acclimation to water stress in trees is often associated with an increase of wood density (Al-Khalifah et al., 2006).

Denser wood shows thicker cell walls and stronger mechanical properties. Aref et al. (2013) studying anatomical adaptive changes of two Acacia woody species concluded that vessel-wall thickness in conjunction with inter-vessel pit membrane thickness showed a positive correlation with water stress in both species. Conversely, Awad et al. (2012) testing ten lines of Populus trema $\times$ Populus alba with modified gene expression of lignin metabolism reported no evidence of the mechanical versus hydraulic trade-off. Instead, they concluded that angiosperm wood species may have numerous ways to accommodate their mechanical properties without interfering with plant hydraulic characteristics.

Testing the relationship between water stress acclimation and mechanical properties in seedlings of three woody species, Christensen-Dalsgaard \& Ennos (2012) emphasized the need for further studies relating physio-chemical parameters and lignin to terrestrial plant hydraulics.

\section{THE ROLE OF LIGNIN IN TERRESTRIAL PLANTS}

Lignins are found widely distributed in both angiosperms and gymnosperms (Figure 1). While in gymnosperms lignins present guaiacyl and syringyl, angiosperms show all three types of lignins i.e., syringyl, hydroxy-phenyl and guaiacyl). Published estimates suggest that lignin represent about $25 \%$ of total plant terrestrial biomass (Boudet et al., 1995). Lignin is a 3-dimensional polymer which is the principal structural component of plant cell wall.

Physiologically, lignin plays an important aspect throughout the life of plants. Lignin affects seed coat which in turn modulates seed dispersal and dehiscence in many plant species (Liljegren et al., 2000). Lignins are also involved in fixation of atmospheric carbon dioxide by forming secondary thickenings of mature terrestrial plants via carbon cycle and by decomposing at an extremely slow rate that replenishes soil fertility and texture. Furthermore, lignification helps in binding plant fibers providing mechanical support to terrestrial plants (Li \& Chapple, 2010).

The synthesis of lignin represents one of the most energy demanding biosynthesic pathway in plants requiring large amounts of carbon skeletons (Amthor, 2003). Lignin is composed of p-hydroxyphenyl (H), guaiacyl (G), and/or syringyl (S) units, the proportions of which vary according to botanical and cytological aspects (Lewis \& Yamamoto, 1990). The glucose requirements for biosynthesis of the three monolignol subunits (i.e., H, G and/or S) are thought to vary, with 


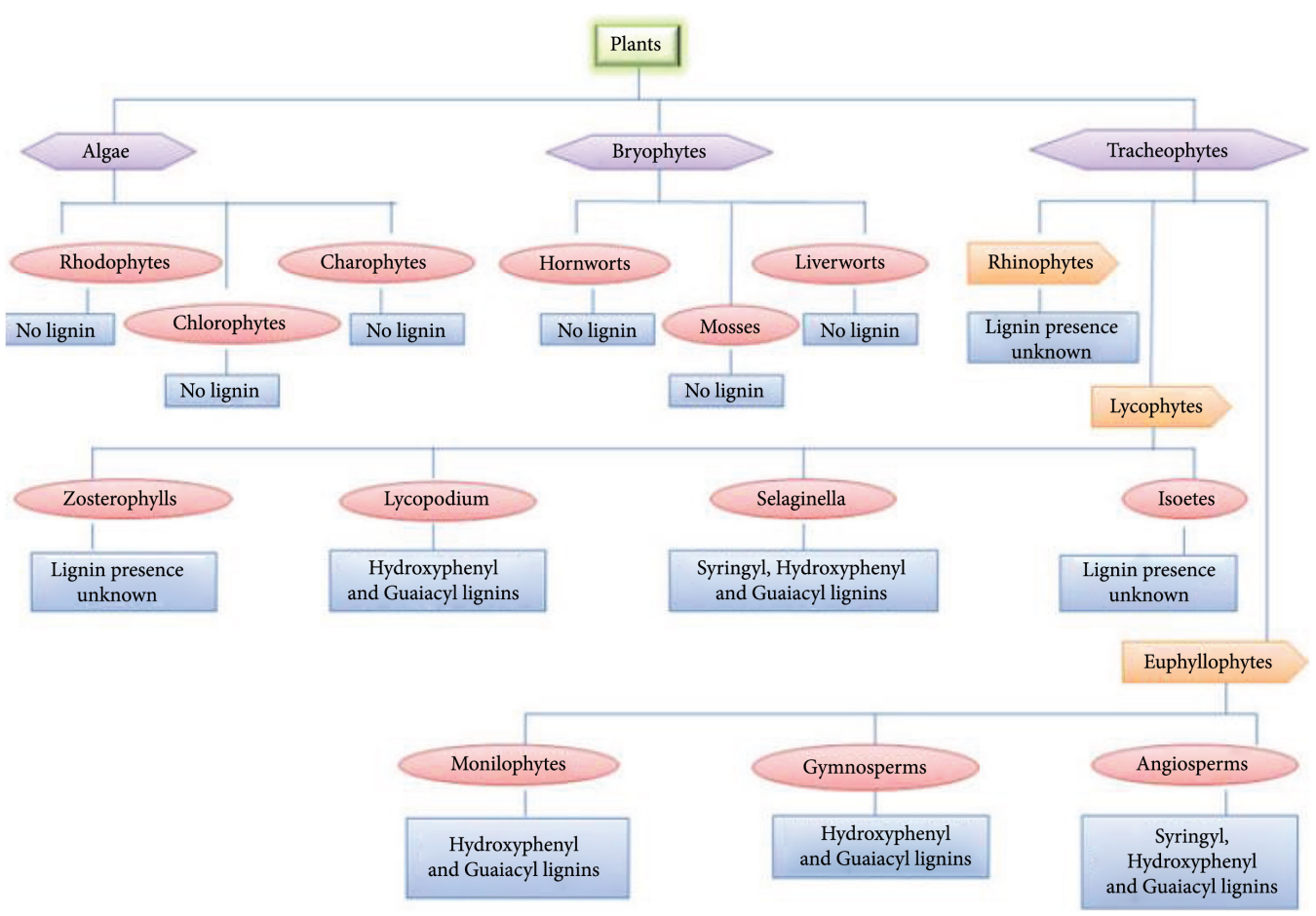

Figure 1. Lignins in the plant kingdom (after Weng \& Chapple, 2010).

$\mathrm{H}$ lignin subunit requiring the least amount of glucose $2.473 \mathrm{~g}$ of glucose per gram of lignin, followed by G lignin subunit $2.547 \mathrm{~g}$ of glucose per gram of lignin, and lastly $S$ lignin subunit requiring $2.600 \mathrm{~g}$ of glucose per gram of lignin (Amthor, 2003).

\section{THE LIGNIFICATION PROCESS}

Lignification is a dynamic physiological process subject to modulation at different levels during normal plant development in response to several environment stresses (Boudet, 2000). The incorporation of lignin into cell walls results in structural rigidity and durability of plant tissues (Lee et al., 2007). Lignin production has been the target of genetic engineering in order to facilitate the production of wood-pulp and biofuel (Vanholme et al., 2008). Several transcription factors controlling lignin biosynthesis genes in response to developmental processes were identified (Osakabe et al., 1999; Boudet et al., 2003; Boerjan et al., 2003; Raes et al., 2003).

Lignin is found in the cell walls of specific tissue types such as traqueids and vessel elements of xylem (Esau, 1967). These cells are characterized by the presence of a specialized cell wall known as the lignified secondary cell wall. During water stress, the cell wall flexibility is affected by the levels of lignin and phenolic compounds (Moore et al., 2008). Within terrestrial plants, lignin content can vary greatly in different tissues. Lignin provides a hydrophobic surface allowing plants to transport water to heights of several meters (Carder, 1995; Koch et al., 2004) as well as contributes to the organism mechanical strength that make trees to support large amounts of biomass (Jagels et al., 2003).

On the other hand, lignin is a limiting factor in a number of agro-industrial processes such as chemical pulping and the processing of lignocellulosic plant biomass to produce bioethanol, as well as modulates forage digestibility. Lignin is very low in young shoots and high in wood. In different tree species, lignin content of wood can vary from $15 \%$ to $40 \%$ (Sarkanen \& Ludwig, 1971) while within a species the average lignin content of wood is much less variable. The manipulation of lignin genes in mutants or transgenic plants suggests the existence of a high degree of plasticity (Lu et al., 2010) despite the fact that modifications are sometimes associated with a strong perturbation in the plant developmental program. In an individual plant, lignin content and composition can vary greatly between different tissues but are much less variable in the same 
tissue when plants are cultivated in standard conditions (Novaes et al., 2010).

\section{LIGNIN AND PLANT FITNESS}

In woody plants, secondary stem growth determines plant size, and responds to physiological and environmental signals. The large amount of assimilated carbon is both accumulated and stored in the secondary cell wall of woody plants, mostly as cellulose and lignin (Osakabe et al., 2012). Stress affects growth and development because plants need to re-allocate energy to adapt to the limiting condition (Skirycz \& Inze, 2010).

According to Pedersen et al. (2005), it appears that reducing lignin content of crop plants can impact their agricultural fitness by reducing lodging resistance, disease resistance and water stress tolerance. However, the relationship among drought tolerance, post-drought recovery and lignin metabolism in plants have not been well revealed (Li et al., 2013).

While lignin biosynthesis is well characterized, the mechanism regulating lignin deposition in response to environmental stresses lacks agreement. The expression levels of the genes encoding cinnamoyl-CoA reductase, which is involved in lignin biosynthesis, increased after drought and localized changes in lignification were involved in the acclimation to drought stress (Fan et al., 2006) and is directly responsible for reduced root colonization by ectomycorrhizae fungi under fertilized conditions (Kleczewski et al., 2010).

In angiosperms, the water-conductive xylem vessel elements of secondary xylem and the primary xylem cells are rich in or contain only guaiacyl (G) lignin subunit, like the tracheids of the more ancient gymnosperms whereas the nonconductive xylem fiber cells are rich in syringyl (S) lignin subunit (Li et al., 2001). The fact that water-conducting cells in both gymnosperms and angiosperms are principally comprised of $\mathrm{G}$ lignin subunit suggests a strong selective pressure to conserve the pathway for and the regulation of $\mathrm{G}$ lignin subunit biosynthesis in the water conducting cells of xylem during land plant evolution (Peter and Neale, 2004). Moreover, transgenic poplars with severe reductions in xylem lignin contents were shown to have a reduced efficiency in water transport (Coleman et al., 2008; Kitin et al., 2010).
Evolution of xylem structure and architecture has been extensively examined from both functional and ecological perspectives (Bhaskar et al., 2007; Meinzer et al., 2010; Sperry et al., 2008). However, little advance has been achieved on the role of cell wall chemistry and in special lignin content and composition in how xylem traits or how xylem evolution affected the deposition and composition of lignin (Boyce et al., 2004).

\section{LIGNIN AND PLANT HYDRAULICS}

Support for the hypothesis that there exist a trade-off between wood strength or stiffness and xylem hydraulic function have been based on essays consisting of surveys across species and environmental gradients (Gartner, 1991a, b; Christensen-Dalsgaard et al., 2007; Jacobsen et al., 2007a, b; Pratt et al., 2007). Rarely addressed is how differences in lignin content may affect wood anatomical or hydraulic properties (Koehler et al., 2006; Horvath et al., 2010).

Results of Terzi et al. (2013) suggested that an increase of water stress could induce lignification in rolled leaves of Ctenanthe setosa. In addition, rubbing the internodes of plants have reduced elongation with alteration of cell wall mechanical properties and accelerated lignification (De Jaegher et al., 1985).

The induction of lignin in plants has been correlated stresses such as cold, drought or light as well as mechanical injuries in a number of plant species such as poplar, rice, pine, Arabidopsis and soybean (Moura et al., 2010). Moura-Sobczak et al. (2011) reported that Eucalyptus urograndis subjected to drought decreased the amount of lignin in the stem apical regions and increased lignin in the basal region while E. globulus showed an opposite behavior in apical regions and showed no significant changes in the basal regions. A hybrid between both species (E. uroglobulus) showed a pattern similar to E. urograndis in apical regions and similar to E. globulus in the basal regions.

Evidence is accumulating that a cell wall integrity sensing and maintenance mechanism exists in plants that coordinates the response to cell wall damage (Seifert \& Blaukopf, 2010). Mechanical stress can have a strong impact on the cell wall composition and architecture. For example, mechanical bending of stems or branches in some angiosperms induces the formation of tension wood containing lignin with an increased S/G ratio (Aoyama et al., 2001). 
Additionally, there is evidence that expression of lignin biosynthetic genes can be correlated with lignin production in response to infection by pathogens such as in Arabidopsis exposed to Xanthomonas campestris, and in Linum usitatissimum cell cultures inoculated with Botrytis cinerea (Lauvergeat et al., 2001; Hano et al., 2006).

\section{FINAL CONSIDERATIONS}

Recent publications have reported that reduction in total lignin content can have a drastic effect on anatomical and physiological traits including reduced growth (Voelker et al., 2010) increased frequency of vessel collapse (Coleman et al., 2008; Kitin et al., 2010) and decreased hydraulic conductivity (Coleman et al., 2008).

Plants present a variety of lignin coordination techniques for monitoring synthesis, accumulation and deposition in response to various intrinsic and extrinsic signals. Lignin plays protective, sustaining and disruptive roles depending upon the situation or stress. Lignin is involved in fixing atmospheric carbon dioxide into secondary thickenings of adult terrestrial plants via the carbon cycle, and decomposes at a low rate compared to most components of dead plant tissues, contributing as a major constituent of humus which maintains soil fertility and texture.

During the lignification process, plant growth is inhibited because the initial enzyme phenylalanine ammonia lyase that is involved in monolignol biosynthesis pathway directly influences accumulation of lignin. Apart from providing mechanical strength, lignin content alteration has been cited during stressed conditions, thereby suggesting that various abiotic stresses have the ability to express the genes responsible for their synthesis.

The potential of altering plant lignin content by scientists and tree managers must be explored in the context to changing environment and anti-stress response triggered by environment stresses.

\section{SUBMISSION STATUS}

Received: 22 apr., 2015

Accepted: 16 july, 2015

\section{CORRESPONDENCE TO}

\section{Ubirajara Contro Malavasi}

Centro de Ciências Agrárias, Universidade

Estadual do Oeste do Paraná - UNIOESTE, Rua Pernambuco, 1777, CP 91, CEP 85960-000, Marechal Candido Rondon, PR, Brasil e-mail: ubirajara.malavasi@unioeste.br

\section{REFERENCES}

Al-Khalifah NS, Khan PR, Al-Abdulkader AM, Nasroun T. Impact of water stress on the sapwood anatomy and functional morphology of Calligonum comosum. IAWA Bull 2006; 27: 299-312.

Ambrose AR, Baxter WL, Wong CS, Næsborg RR, Williams CB, Dawson TE. Contrasting drought-response strategies in California redwoods. Tree Physiology 2015; 35(5): 453-469. http://dx.doi.org/10.1093/treephys/tpv016. PMid:25787330.

Amthor JS. Efficiency and lignin biosynthesis: a quantitative analysis. Annals of Botany 2003; 91(6): 673-695. http:// dx.doi.org/10.1093/aob/mcg073. PMid:12714366.

Aoyama W, Matsumura A, Tsutsumi Y, Nishida T. Lignification and peroxidase in tension wood of Eucalyptus viminalis seedlings. Journal of Wood Science 2001; 47(6): 419-424. http://dx.doi.org/10.1007/BF00767892.

Aref IM, Ahmed AI, Khan PR, El-Atta HA, Iqbal M. Drought-induced adaptive changes in the seedling anatomy of Acacia ehrenbergiana and Acacia tortilis subsp. Raddiana. Trees 2013; 27(4): 959-971. http://dx.doi.org/10.1007/ s00468-013-0848-2.

Arnell NW. Climate change and global water resources: SRES emissions and socio-economic scenarios. Global Environmental Change 2004; 14(1): 31-52. http://dx.doi. org/10.1016/j.gloenvcha.2003.10.006.

Awad H, Herbette S, Brunel N, Tixier A, Pilate G, Cochard $\mathrm{H}$ et al. No trade-off between hydraulic and mechanical properties in several transgenic poplars modified for lignins metabolism. Environmental and Experimental Botany 2012; 77: 185-195. http://dx.doi.org/10.1016/j. envexpbot.2011.11.023.

Bhaskar R, Valiente-Banuet A, Ackerly DD. Evolution of hydraulic traits in closely related species pairs from mediterranean and nonmediterranean environments of North America. The New Phytologist 2007; 176(3): 718726. http://dx.doi.org/10.1111/j.1469-8137.2007.02208.x. PMid:17897324.

Boerjan W, Ralph J, Baucher M. Lignin biosynthesis. Annual Review of Plant Biology 2003; 54(1): 519-546. http:// dx.doi.org/10.1146/annurev.arplant.54.031902.134938. PMid:14503002. 
Boudet AM, Kajita S, Grima-Pettenati J, Goffner D. Lignins and lignocellulosics: a better control of synthesis for new and improved uses. Trends in Plant Science 2003; 8(12): 576-581. http://dx.doi.org/10.1016/j.tplants.2003.10.001. PMid:14659706.

Boudet AM, Lapierre C, Grima-Pettenati J. Biochemistry and molecular biology of lignification. The New Phytologist 1995; 129(2): 203-236. http://dx.doi.org/10.1111/j.1469-8137.1995. tb04292.x.

Boudet AM. Lignins and lignification: selected issues. Plant Physiology and Biochemistry 2000; 38(1-2): 81-96. http://dx.doi.org/10.1016/S0981-9428(00)00166-2.

Boyce CK, Zwieniecki MA, Cody GD, Jacobsen C, Wirick $\mathrm{S}$, Knoll AH et al. Evolution of xylem lignification and hydrogel transport regulation. Proceedings of the National Academy of Sciences of the United States of America 2004; 101(50): 17555-17558. http://dx.doi.org/10.1073/ pnas.0408024101. PMid:15574502.

Brodribb TJ, Cochard H. Hydraulic failure defines the recovery and point of death in water-stressed conifers. Plant Physiology 2009; 149(1): 575-584. http://dx.doi. org/10.1104/pp.108.129783. PMid:19011001.

Carder AC. Forest giants of the world, past and present. Markham: Fitzhenry \& Whiteside; 1995.

Christensen-Dalsgaard KK, Ennos AR. Effects of drought acclimation on the mechanical properties of Ochroma pyramidale, Betula pendula and Acacia karroo tree seedling stems. Forestry 2012; 85(2): 215-223. http:// dx.doi.org/10.1093/forestry/cpr061.

Christensen-Dalsgaard KK, Fournier M, Ennos AR, Barfod AS. Changes in vessel anatomy in response to mechanical loading in six species of tropical trees.. The New Phytologist 2007; 176(3): 610-622. http://dx.doi. org/10.1111/j.1469-8137.2007.02227.x. PMid:17953543.

Cochard H, Cruiziat P, Tyree MT. Use of positive pressures to establish vulnerability curves. Further support for the air-seeding hypothesis and implications for pressurevolume analysis. Plant Physiology 1992; 100(1): 205-209. http://dx.doi.org/10.1104/pp.100.1.205. PMid:16652947.

Coleman HD, Samuels AL, Guy RD, Mansfield SD. Perturbed lignification impacts tree growth in hybrid poplar - a function of sink strength vascular integrity, and photosynthetic assimilation. Plant Physiology 2008; 148(3): 1229-1237. http://dx.doi.org/10.1104/pp.108.125500. PMid:18805953.

De Jaegher G, Boyer N, Gaspar TH. Thigmomorphogenesis in Bryonia dioica: changes in soluble and wall peroxidases, phenylalanine ammonia-lyase activity, cellulose, lignin content and monomeric constituents. Plant Growth Regulation 1985; 3(2): 133-148. http://dx.doi.org/10.1007/ BF01806053.

De Micco V, Aronne G. Morpho-anatomical traits for plant adaptation to drought. In: Aroca R, editor. Plant responses to drought stress. Berlin: Springer-Verlag; 2012.
Esau K. Plant anatomy. New York: Wiley; 1967.

Fan L, Linker R, Gepstein S, Tanimoto E, Yamamoto R, Neumann PM. Progressive inhibition by water deficit of cell wall extensibility and growth along the elongation zone of maize roots is related to increased lignin metabolism and progressive stellar accumulation of wall phenolics. Plant Physiology 2006; 140(2): 603-612. http://dx.doi. org/10.1104/pp.105.073130. PMid:16384904.

Gartner B. Stem hydraulic properties of vines versus shrubs of western poison oak Toxicodendron diversilobum. Oecologia 1991a; 87(2): 180-189. http://dx.doi.org/10.1007/ BF00325255.

Gartner B. Structural stability and architecture of vines versus shrubs of poison oak Toxicodendron diversilobum. Ecology 1991b; 72(6): 2005-2015. http://dx.doi.org/10.2307/1941555.

Hacke UG, Sperry JS, Pockman WT, Davis SD, McCulloh KA. Trends in wood density and structure are linked to prevention of xylem implosion by negative pressure. Oecologia 2001; 126(4): 457-461. http://dx.doi.org/10.1007/ s004420100628.

Hacke UG, Sperry JS, Wheeler JK, Castro L. Scaling of angiosperm xylem structure with safety and efficiency. Tree Physiology 2006; 26(6): 689-701. http://dx.doi.org/10.1093/ treephys/26.6.689. PMid:16510385.

Hano C, Addi M, Bensaddek L, Cronier D, BaltoraRosset S, Doussot J et al. Differential accumulation of monolignol-derived compounds in elicited flax (Linum usitatissimum) cell suspension cultures. Planta 2006; 223(5): 975-989. http://dx.doi.org/10.1007/s00425-0050156-1. PMid:16292660.

Horvath B, Peszlen I, Peralta P, Kasal B, Li L. Effect of lignin genetic modification on wood anatomy of aspen trees. International Association of Wood Anatomists 2010; 31: $29-38$

Jacobsen AL, Agenbag L, Esler KJ, Pratt RB, Ewers FW, Davis SD. Xylem density, biomechanics, and anatomical traits correlate with water stress in 17 evergreen shrub species of the Mediterranean-type climate region of South Africa. Journal of Ecology 2007a; 95(1): 171-183. http:// dx.doi.org/10.1111/j.1365-2745.2006.01186.x.

Jacobsen AL, Ewers FW, Pratt RB, Paddock WA 3rd, Davis SD. Do xylem fibers affect vessel cavitation resistance? Plant Physiology 2005; 139(1): 546-556. http://dx.doi. org/10.1104/pp.104.058404. PMid:16100359.

Jacobsen AL, Pratt RB, Ewers FW, Davis SD. Cavitation resistance among twenty-six chaparral species of southern California. Ecological Monographs 2007b; 77(1): 99-115. http://dx.doi.org/10.1890/05-1879.

Jagels R, Visscher GE, Lucas J, Goodell B. Paleo-adaptive properties of the xylem of Metasequoia: mechanical/ hydraulic compromises. Annals of Botany 2003; 92(1): 79-88. http://dx.doi.org/10.1093/aob/mcg117. PMid:12763758. 
Jansen S, Choat B, Pletsers A. Morphological variation of intervessel pit membranes and implications to xylem function in angiosperms. American Journal of Botany 2009; 96(2): 409-419. http://dx.doi.org/10.3732/ajb.0800248. PMid:21628196.

Kitin P, Voelker SL, Meinzer FC, Beeckman H, Strauss SH, Lachenbruch B. Tyloses and phenolic deposits in xylem vessels impede water transport in lowlignin transgenic poplars: a study by cryo-fluorescence microscopy. Plant Physiology 2010; 154(2): 887-898. http://dx.doi.org/10.1104/ pp.110.156224. PMid:20639405.

Kleczewski NM, Herms DA, Bonello P. Effects of soil type, fertilization and drought on carbon allocation to root growth and partitioning between secondary metabolism and ectomycorrhizae of Betula papyrifera. Tree Physiology 2010; 30(7): 807-817. http://dx.doi.org/10.1093/treephys/ tpq032. PMid:20462938.

Koch GW, Sillett SC, Jennings GM, Davis SD. The limits to tree height. Nature Biotechnology 2004; 428(6985): 851-854. PMid:15103376.

Koehler L, Ewers FW, Telewski FW. Optimizing for multiple functions: mechanical and structural contributions of cellulose microfibrils and lignin in strengthening tissues. In: Stokke DD, Groom LH, editors. Characterization of the cellulosic cell wall. USA: Blackwell Publishing; 2006.

Lauvergeat V, Lacomme C, Lacombe E, Lasserre E, Roby D, Grima-Pettenati J. Two cinnamoyl-CoA reductase (CCR) genes from Arabidopsis thaliana are differentially expressed during development and in response to infection with pathogenic bacteria. Phytochemistry 2001; 57(7): 11871195. http://dx.doi.org/10.1016/S0031-9422(01)00053-X. PMid:11430991.

Lee BR, Kim KY, Jung WJ, Avice JC, Ourry A, Kim TH. Peroxidases and lignification in relation to the intensity of water deficit stress in white clover (Trifolium repens L.). Journal of Experimental Botany 2007; 58(6): 1271-1279. http://dx.doi.org/10.1093/jxb/erl280. PMid:17298963.

Lewis NG, Yamamoto E. Lignin: occurrence, biogenesis and biodegradation. Annual Review of Plant Physiology and Plant Molecular Biology 1990; 41(1): 455-496. http:// dx.doi.org/10.1146/annurev.pp.41.060190.002323. PMid:11543592.

Li L, Cheng XF, Leshkevich J, Umezawa T, Harding SA, Chiang VL. The last step of syringyl monolignol biosynthesis in angiosperms is regulated by a novel gene encoding sinapyl alcohol dehydrogenase. The Plant Cell 2001; 13(7): 1567-1586. http://dx.doi.org/10.1105/ tpc.13.7.1567. PMid:11449052.

Li X, Chapple C. Understanding Lignification: challenges beyond monolignol biosynthesis. Plant Physiology 2010; 154(2): 449-452. http://dx.doi.org/10.1104/pp.110.162842. PMid:20921161.

Li Z, Peng Y, Ma X. Different response on drought tolerance and post-drought recovery between the small-leafed and the large-leafed white clover (Trifolium repens L.) associated with antioxidative enzyme protection and lignin metabolism. Acta Physiologiae Plantarum 2013; 35(1): 213-222. http://dx.doi.org/10.1007/s11738-012-1066-z.

Liljegren S, Ditta G, Eshed Y, Savidge B, Bowman J, Yanofsky M. Control of fruit dehiscence in Arabidopsis by the SHATTERPROOF MADS-box genes. Nature 2000; 404(6779): 766-769. http://dx.doi.org/10.1038/35008089. PMid:10783890.

Lisar SYS, Motafakkerazad R, Hossain MM, Rahman IMM. Water stress in plants: causes, effect and responses. In: Rahman IM, Hasegawa H, editors. Water stress. Rijeka: Intech Publishers; 2012.

Lobell DB, Gourdji SM. The influence of climate change on global crop productivity. Plant Physiology 2012; 160(4): 1686-1697. http://dx.doi.org/10.1104/pp.112.208298. PMid:23054565.

Lu F, Marita JM, Lapierre C, Jouanin L, Morreel K, Boerjan W et al. Sequencing around 5-hydroxyconiferyl alcoholderived units in caffeic acid Omethyltransferase-deficient poplar lignins. Plant Physiology 2010; 153(2): 569-579. http://dx.doi.org/10.1104/pp.110.154278. PMid:20427467.

Maherali H, Pockman WT, Jackson RB. Adaptive variation in the vulnerability of woody plants to xylem cavitation. Ecology 2004; 85(8): 2184-2199. http://dx.doi. org/10.1890/02-0538.

McDowell N, Pockman WT, Allen CD, Breshears DD, Cobb N, Kolb T et al. Mechanisms of plant survival and mortality during drought: why do some plants survive while others succumb to drought? The New Phytologist 2008; 178(4): 719-739. http://dx.doi.org/10.1111/j.14698137.2008.02436.x. PMid:18422905.

Meinzer FC, Mcculloh KA, Lachenbruch B, Woodruff DR, Johnson DM. The blind men and the elephant: the impact of context and scale in evaluating conflicts between plant hydraulic safety and efficiency. Oecologia 2010; 164(2): 287-296. http://dx.doi.org/10.1007/s00442-010-1734-x. PMid:20668883.

Moore JP, Vicre-Gibouin M, Farrant JM, Driouich A. Adaptations of higher plant cell walls to water loss: drought vs desiccation. Physiologia Plantarum 2008; 134(2): 237 245. http://dx.doi.org/10.1111/j.1399-3054.2008.01134.x. PMid:18494857.

Moura JCMS, Bonine CAV, De Oliveira Fernandes Viana J, Dornelas MC, Mazzafera P. Abiotic and biotic stresses and changes in the lignin content and composition in plants. Journal of Integrative Plant Biology 2010; 52(4): 360-376. http://dx.doi.org/10.1111/j.1744-7909.2010.00892.x. PMid:20377698.

Moura-Sobczak J, Souza U, Mazzafera P. Drought stress and changes in the lignin content and composition in Eucalyptus. In: Proceedings of the IUFRO Tree Biotechnology Conference; 2011; Arraial d'Ajuda, Bahia, Brazil. London: BioMed Central; 2011. 103 p. 
Munns R. Comparative physiology of salt and water stress. Plant, Cell \& Environment 2002; 25(2): 239-250. http://dx.doi.org/10.1046/j.0016-8025.2001.00808.x. PMid:11841667.

Novaes E, Kirst M, Chiang V, Winter-Sederoff H, Sederoff R. Lignin and biomass: a negative correlation for wood formation and lignin content in trees. Plant Physiology 2010; 154(2): 555-561. http://dx.doi.org/10.1104/pp.110.161281. PMid:20921184.

Osakabe K, Tsao CC, Li L, Popko JL, Umezawa T, Carraway DT et al. Coniferyl aldehyde 5-hydroxylation and methylation direct syringyl lignin biosynthesis in angiosperms. Proceedings of the National Academy of Sciences of the United States of America 1999; 96(16): 8955-8960. http://dx.doi.org/10.1073/pnas.96.16.8955. PMid:10430877.

Osakabe Y, Kawaoka A, Nishikubo N, Osakabe K. Responses to environmental stresses in woody plants: key to survive and longevity. Journal of Plant Research 2012; 125(1): 1-10. http://dx.doi.org/10.1007/s10265011-0446-6. PMid:21874628.

Pedersen JF, Vogel KP, Funnell DL. Impact of reduced lignin on plant fitness. Crop Science 2005; 45(3): 812-819. http://dx.doi.org/10.2135/cropsci2004.0155.

Pennisi E. Plant genetics: the blue revolution, drop by drop, gene by gene. Science 2008; 320(5873): 171-173. http:// dx.doi.org/10.1126/science.320.5873.171. PMid:18403686.

Peter G, Neale D. Molecular basis for the evolution of xylem lignification. Current Opinion in Plant Biology 2004; 7(6): 737-742. http://dx.doi.org/10.1016/j.pbi.2004.09.002. PMid:15491924.

Pinto JR, Marshall JD, Dumroese RK, Davis AS, Cobos DR. Photosynthetic response, carbon isotopic composition, survival, and growth of three stock types under water stress enhanced by vegetative competition. Canadian Journal of Forest Research 2012; 42(2): 333-344. http:// dx.doi.org/10.1139/x11-189.

Pockman WT, Sperry JS. Vulnerability to xylem cavitation and the distribution of Sonoran desert vegetation. American Journal of Botany 2000; 87(9): 1287-1299. http://dx.doi. org/10.2307/2656722. PMid:10991900.

Pratt RB, Jacobsen AL, Ewers FW, Davis SD. Relationships among xylem transport, biomechanics, and storage in stems and roots of nine Rhamnaceae species of the California chaparral. The New Phytologist 2007; 174(4): 787-798. http://dx.doi.org/10.1111/j.1469-8137.2007.02061.x. PMid:17504462.

Raes J, Rohde A, Christensen JH, Van de Peer Y, Boerjan W. Genome-wide characterization of the lignification toolbox in Arabidopsis. Plant Physiology 2003; 133(3): 1051-1071. http://dx.doi.org/10.1104/pp.103.026484. PMid:14612585.
Sarkanen KV, Ludwig CH. Lignins: occurrence, formation, structure and reactions. New York: John Wiley \& Sons; 1971.

Seifert GJ, Blaukopf C. Irritable walls: the plant extracellular matrix and signaling. Plant Physiology 2010; 153(2): 467-478. http://dx.doi.org/10.1104/pp.110.153940. PMid:20154095.

Shen FY, Guo R, Sun Q, Gao RF, Shen YB, Zhang ZY. Possible causes for embolism repair in xylem. Environmental and Experimental Botany 2007; 62(2): 139-144. http://dx.doi. org/10.1016/j.envexpbot.2007.07.015

Skirycz A, Inze D. More from less: plant growth under limited water. Current Opinion in Biotechnology 2010; 21(2): 197-203. http://dx.doi.org/10.1016/j.copbio.2010.03.002. PMid:20363612.

Sperry JS, Meinzer FC, Mcculloh KA. Safety and efficiency conflicts in hydraulic architecture: scaling from tissues to trees. Plant, Cell \& Environment 2008; 31(5): 632-645. http://dx.doi.org/10.1111/j.1365-3040.2007.01765.x. PMid:18088335.

Sperry JS, Perry AH, Sullivan JEM. Pit membrane degradation and air embolism formation in ageing xylem vessels of Populus tremuloides Michx. Journal of Experimental Botany 1991; 42(244): 1399-1406. http:// dx.doi.org/10.1093/jxb/42.11.1399.

Terzi R, Saruhan Güler N, Kutlu Çalişkan N, Kadioğlu A. Lignification response for rolled leaves of Ctenanthe setosa under long-term drought stress. Turkish Journal of Biology 2013; 37: 614-619. http://dx.doi.org/10.3906/ biy-1210-27.

Tyree MT, Engelbrecht BMH, Vargas G, Kursar TA. Desiccation tolerance of five tropical seedlings in Panama: relationship to a field assessment of drought performance. Plant Physiology 2003; 132(3): 1439-1447. http://dx.doi. org/10.1104/pp.102.018937. PMid:12857825.

Tyree MT, Zimmermann MH. Xylem structure and the ascent of sap. Berlin: Springer Verlag; 2002.. http://dx.doi. org/10.1007/978-3-662-04931-0.

Tyree MT. The cohesion-tension theory of sap ascent: current controversies. Journal of Experimental Botany 1997; 48: 1753-1765.

Vanholme R, Morreel K, Ralph J, Boerjan W. Lignin engineering. Current Opinion in Plant Biology 2008; 11(3): 278-285. http://dx.doi.org/10.1016/j.pbi.2008.03.005. PMid:18434238.

Voelker SL, Lachenbruch B, Meinzer FC, Jourdes M, Ki C, Patten AM et al. Antisense down-regulation of 4CL expression alters lignification, tree growth, and saccharification potential of field-grown poplar. Plant Physiology 2010; 154(2): 874-886. http://dx.doi.org/10.1104/ pp.110.159269. PMid:20729393.

Weng JK, Chapple C. The origin and evolution of lignin biosynthesis. The New Phytologist 2010; 187(2): 273-285. http://dx.doi.org/10.1111/j.1469-8137.2010.03327.x. PMid:20642725. 